\title{
The Impact of Governance on Entrepreneurship Development in ASEAN+1 Countries: Evidence from World Bank Datasets
}

\author{
Thai Thanh Ha${ }^{1}$, Nguyen Ngoc Chau ${ }^{2}$, Nguyen Trung Hieu ${ }^{3}$ \\ ${ }^{1}$ Department of Academic Affairs and Training, National Academy of Public Administration, Hanoi, Vietnam \\ ${ }^{2}$ Department of Economics and Investment, Hue College of Economic, Hue City, Vietnam \\ ${ }^{3}$ Department of Language and International Culture, Hong Bang International University, Ho Chi Minh City, \\ Vietnam \\ Email: thaiha63@yahoo.com,wanjunghyo@gmail.com
}

Received 31 March 2016; accepted 30 April 2016; published 3 May 2016

Copyright (C 2016 by authors and Scientific Research Publishing Inc.

This work is licensed under the Creative Commons Attribution International License (CC BY). http://creativecommons.org/licenses/by/4.0/

(c) $\underset{\mathrm{EY}}{\mathrm{Er}}$ Open Access

\section{Abstract}

This research explores the impact of the governance indices on the development of entrepreneurship in the context of ASEAN+1 countries which include China as an important partner to South East Asian nations in almost all aspects of ASEAN development. With the use of the database of the World Bank on the World Governance Indices and Entrepreneurship known as Doing Business for ASEAN+1 countries, natural logarithm regression analysis was adopted to figure out the extent to which governance would exert its impact on the entrepreneurship development in the member countries of ASEAN as well as China. On the basis of the study findings, conclusions and recommendations were to be drawn for policy modernization in ASEAN+1 context.

\section{Keywords}

Impacts, Governance, Entrepreneurship Development, ASEAN, China

\section{Introduction}

Governance has recently become a buzzword both in government and corporate policy-making circles [1] [2]. While it is defined as the process and institutions by which authority in a country is exercised [3], entrepreneurship is considered as a tool for economic growth and innovation across countries regardless of stages of devel- 
opment [4]. In many ways, entrepreneurship is critical to the well-being of society [5]. Therefore, resolving the conundrum of the governance-entrepreneurship nexus has been an important area of policy research and discussion in recent years [6]. This is also the case in point for ASEAN, which is composed of ten member states with a unitary motto also known as "one vision, one identity, one community". Yet, governance trends in ASEAN are not linear and cannot be applied nor have been imported generally across borders. ASEAN's growing middle class, now estimated at nearly 100 million, is making its voice heard [7]-[9]. That trend is one that is strengthening ASEAN itself when it is in an important talk of many issues with China [10] [11]. ASEAN countries have to try harder to tidily array the relationship between governance and entrepreneurship development with the aim at boosting the economic growth. This, in turn, will empower the ASEAN block to maintain a fair position with China on the basis of good governance practices and favorable environment for business start-up and doing business, thereby increasing its competitiveness [12]. Given the lack of empirical evidence, the purpose of this research is to assess the impact of governance on the entrepreneurship in this spotlight region. This not only should set more light on the issue, but also would draw policy implications for ASEAN to confidently enter its most contentious period since the establishment of this organization [13]. We include China into this kind of empirical research because of its key role that plays not only in the international arena, but also in the South East Asian region [14]. By the same token, China still plays an important role for ASEAN in all facets of political socio-economic and cultural development. Therefore, results of this research helps draw a broad picture that goes beyond ASEAN countries itself.

\section{Literature Review}

Entrepreneurship is an important driver shaping the changes in the economic landscape regardless of its occurrence either in formal economy or informal sector outside the state regulatory systems [15]-[19]. At the macro level, it is useful for policy makers to understand what drives entrepreneurs to set up their business [18]. Especially, being knowledgeable of institutional hindrances to business start-up can help them not only understand the current situation, but also come up with policy measures in order to keep their countries' entrepreneurship development on the right track. In this process, Bjørnskov and Foss [20] and Wennekers et al. [21] reckon that governance plays a critical role in making that happen.

Gedeon [22] has made a thorough review of literature on the field and come further to a conclusion that the level of entrepreneurship varies systematically across countries. It has been argued that factors such as economic conditions and institutions and so on are important determinants for entrepreneurship to prosper [23]-[26].

Across ASEAN countries it is also widely argued that good governance also nurses entrepreneurship development [5] [6] [12] [27] [28]. However, fostering the entrepreneurship development requires the government efficiency to be sustained on a long-term basis [29]. Governments can take a variety of actions in favor of entrepreneurial activities by increasing quality of governance [18]. However, measures to encourage people to register their entrepreneurial activities through improved governance quality may not be feasible for countries in low economic development stages [18]. On the one hand, the regulatory environment is generally weak in such countries, and people can gain legitimacy without the government's support in developing countries [30] [31]. On the other hand, they may have some doubts about its protective ability due to deep-rooted rampant corruption, and thus, are more unlikely to register their business or to operate in the formal sector [32].

In explaining that phenomenon Morrison [33] cites the cultural and societal specificity as the triggers of the entrepreneurship. Other scholars such as Troilo [34]; Peter and Savoir [35]; Cressy et al. [36] argue that it is made possible because trust in government effectiveness, political stability, rule of law, and voice in government affairs should be related to citizens' willingness to take risks associated with investing, starting and managing new businesses. Friedman et al. [4] conclude that the economic, social and self-actualization benefits of starting up and managing new businesses must, ultimately, outweigh the risks and burdens in order for entrepreneurship to occur. A comprehensive review made by several scholars such as Friedman [4]; Gedeon [10]; Khorshed [37]; Lowrey [37]; Thai and Turkina [18] show that studies which identify the impact of governance on the entrepreneurship development are limited. Yet, conflicting results sometimes appear, leading to the fact that more research is, therefore, needed in this area. Established measures of governance and entrepreneurship are described below.

\subsection{World Governance Indicators}

Kaufmann et al. [38] draw on existing notions of governance, and seek to navigate between overly broad and 
narrow definitions, to define governance as "the traditions and institutions by which authority in a country is exercised. This includes 1) the process by which governments are selected, monitored and replaced; 2) the capacity of the government to effectively formulate and implement sound policies; and 3) the respect of citizens and the state for the institutions that govern economic and social interactions among them". Therefore, two measures of governance corresponding to each of these three areas, resulting in a total of six dimensions of governance which include:

1) Voice and Accountability (VA)—capturing perceptions of the extent to which a country's citizens are able to participate in selecting their government, as well as freedom of expression, freedom of association, and a free media.

2) Political Stability and Absence of Violence (PV)—capturing perceptions of the likelihood that the government will be destabilized or overthrown by unconstitutional or violent means, including politically-motivated violence and terrorism.

3) Government Effectiveness (GE) — capturing perceptions of the quality of public services, the quality of the civil service and the degree of its independence from political pressures, the quality of policy formulation and implementation, and the credibility of the government's commitment to such policies.

4) Regulatory Quality (RQ) — capturing perceptions of the ability of the government to formulate and implement sound policies and regulations that permit and promote private sector development.

5) Rule of Law (RL) - capturing perceptions of the extent to which agents have confidence in and abide by the rules of society, and in particular the quality of contract enforcement, property rights, the police, and the courts, as well as the likelihood of crime and violence.

6) Control of Corruption (CC)_capturing perceptions of the extent to which public power is exercised for private gain, including both petty and grand forms of corruption, as well as "capture" of the state by elites and private interests.

\subsection{Entrepreneurship}

Entrepreneurship scholars have yet to reach a common definition of the concept on entrepreneurship [39]. Depending on the research focus and interest, a variety of entrepreneurship definitions is used [40]. According to Thai and Turkina [18] there are four streams of entrepreneurship research that adopt four different views on the functions of entrepreneurs in the economy. Amorós and Bosma [5] who argue that entrepreneurs are driven to start up their business by "push" and "pull” motivations in order to better understand the entrepreneurial phenomenon. In this connection, data produced by the Global Entrepreneurship Monitor (GEM) or the World Bank have become increasingly popular in recent studies [5] [41]. In this research, we adopt this popular trend in entrepreneurship research by examining World Bank datasets. These data offer different measures of new business starts and doing business, and each with different coverage in terms of years and countries. This World Bank's largest entrepreneurship dataset in terms of the greatest number of country-years is available online at the doingbusiness.org webpage [42]. As at January 2014, the World Bank sample comprises entrepreneurship information from 2004-2014 for more than 120 countries. The reason for adopting these datasets is the compatibility or corresponding measures in terms of time and methods as compared to the dataset on World Governance Indicators also created by the World Bank. Furthermore, by selecting five types of hindrance for entrepreneurs to start up and run their business such as: 1) Cost of starting a business; 2) Property registration cost; 3) Cost of export; 4) Cost of import; and 5) Time needed for contract enforcement, we try to look into the entrepreneurship phenomenon from a "hindrance" angle rather than a "motivational factor" lenses. In so-doing, we attempt to empirically test the explanatory power of governance determinants of entrepreneurship that have been theoretically developed, yet still neglected by the other scholars.

\section{Research Model and Hypotheses}

\subsection{Research Model}

To quantify the impact of governance on the entrepreneurship, we used five types of common costs/expenditures that entrepreneurs are often faced with in a certain country. Therefore, let a number of independent variables $Y$ Cost $_{i j}$ respectively be the natural logarithm of $\left(\boldsymbol{C}^{\mathbf{1}}\right)$ Cost of starting a business which is calculated as percentage of income per capita; $\left(C^{2}\right)$ Property registration cost which is referred to as the cost to be at the percentage of property value; $\left(C^{3}\right)$ Cost to export as the absolute US\$ per container; $\left(C^{4}\right)$ Cost to import which is incurred at an 
amount of US\$ per container; $\left(T^{5}\right)$ Time needed for contract enforcement calculated as the amount of days that entrepreneurs are in need for completely enforcing the contract for ASEAN country $\boldsymbol{i}$ during the period $\boldsymbol{j}$. The impact of governance can be tested using the following equation for five respective independent variables as mentioned above:

$$
\operatorname{LnYC} C_{i j}^{n} \text { or } T_{i j}^{5}=\propto_{0 i}+\sum_{j=1}^{9} B_{j} N_{j}+\sum_{k=1}^{6} \gamma_{k i} \operatorname{Ln} W_{k i}+\varepsilon_{i j}
$$

\section{where:}

$\operatorname{LnYC} C_{i j}^{n}$ is natural logarithm of $\operatorname{cost}_{n}(n=$ from 1 to 4 ) and time needed for contract enforcement as described above for country $j$ at the year $i$.

$\propto_{0 i}$ is the natural logarithm regression constant.

$\sum_{j=1}^{9} B_{j} N_{j}$ is the vector of dummy variables for nine ASEAN countries and China.

$\sum_{k=1}^{6} \gamma_{k i} \operatorname{Ln} W_{k i}$ is the vector of World Governance Indicators from 1st to 6th.

$\varepsilon_{i j}$ is residual term in the model.

ASEAN +1 countries included in the analysis are composed of 10 following nations: Brunei Darussalam (BR); Cambodia (KH); China (CH); Indonesia (IN); Laos (LA); Malaysia (MA); the Philippines (PH); Singapore (SI); Thailand (TH); Vietnam (VN). Myanmar is not brought into the model and analysis due to the unavailability of the data. Thus, for a polytomous factor of 10 countries there is a need to code 9 dummy variables. In this regression analysis, Singapore serves as a baseline to which other countries are compared in the regression analysis.

The above-mentioned econometric model would also allow the overcoming of the normality condition or statistical normality test known as Kolmogorov-Smirnov test (Ha et al., 2012; Hair et al., 2008). When it boiled down to the number of specific independent variables, the regression equation could be concretely expanded, with Singapore as a baseline dummy variable, in the following forms:

$$
\begin{aligned}
Y_{C^{n}} \text { or } Y_{T^{5}}= & \alpha_{0}+\beta_{n 1}(\mathrm{BR})+\beta_{n 2}(\mathrm{KH})+\beta_{n 3}(\mathrm{CH})+\beta_{n 4}(\mathrm{IN})+\beta_{n 5}(\mathrm{LA}) \\
& +\beta_{n 6}(\mathrm{MA})+\beta_{n 7}(\mathrm{PH})+\beta_{n 8}(\mathrm{TH})+\beta_{n 9}(\mathrm{VN})+\gamma_{n 1}(\mathrm{VA}) \\
& +\gamma_{n 2}(\mathrm{PV})+\gamma_{n 3}(\mathrm{GE})+\gamma_{n 4}(\mathrm{RQ})+\gamma_{n 5}(\mathrm{RL})+\gamma_{n 6}(\mathrm{CC})+\zeta
\end{aligned}
$$

where:

BR; KH; CH; IN; LA; MA; PH; TH; VN are dummy variables for nine ASEAN countries plus China. The data of independent variables are extracted from the World Bank on-line webpage concerning the World Governance Indicators to be used in the Equation (1). Namely,

$C^{n}$ : Dependent variables with $n$ ranging from 1 to 4 representing four types of costs hindering the entrepreneurs in ASEAN plus One.

$T^{5}$ : Representing the amount of time needed for contract enforcement.

VA: is the Voice and Accountability.

PV: is the Political Stability and Absence of Violence.

GE: is the Government Effectiveness.

RQ: is the Regulatory Quality.

RL: is the Rule of Law.

CC: is the Control of Corruption.

\subsection{Hypotheses}

As it is confirmed in the works of several scholars [4] [18] [20] [38] [43] entrepreneurship flourishes under favorable governance conditions. This also means good governance is helpful to reduce the hindrances and barriers for entrepreneurship. Therefore, governance is of good quality only when starting and doing business would cost the entrepreneurs with acceptable amount of money and time. More importantly, it would entail such beliefs as trust in government effectiveness, political stability. The rule of law must also exist to ensure an acceptable level of certainty to bring about a situation in which contractual obligations are met [18]. Given the 
above mentioned reasoning the specific hypotheses are developed as follows:

Hypothesis 1: Across ASEAN+1 countries, the governance is negatively impacted by the cost of starting a business.

Hypothesis 2: Across ASEAN+1 countries, the governance is negatively impacted by property registration cost.

Hypothesis 3: Across ASEAN+1 countries, the governance is negatively impacted by cost of export.

Hypothesis 4: Across ASEAN+1 countries, the governance is negatively impacted by cost of import.

Hypothesis 5: Across ASEAN+1 countries, the governance is negatively impacted by Time needed for contract enforcement.

Hypothesis 6: Across ASEAN+1 countries, the degree to which governance exerts impact on costs of doing business and time for contract enforcement is different.

Hypothesis testing should be conducted using the above mentioned econometric model (1) with regards to the impact of governance on the entrepreneurship using the 2004-2014 World Bank dataset as described above.

\section{Data Analysis and Discussion}

\subsection{Descriptive Statistics}

The ASEAN+1 yearly entrepreneurship data were taken from the World Bank dataset from the year of 2004 to 2014. At the same time, yearly data on six dimensional governance indicators for ASEAN countries and China were also retrieved from the World Bank for the period of 2004-2014 [44]. Due to the data unavailability for some countries at point in time, we used the mean series method to replace the missing values of the WGI data for the year of 2013 and 2014 consecutively. All of these six dependent predictors were consecutively regressed against the five dependent variables with a set of nine dummy variables with an exclusion of Myanmar. Descriptive statistics are shown for ASEAN+1 below:

Mean values and standard deviations for ASEAN countries and China are presented in Table 1. China scored higher rankings on such indicators as Regulatory Quality (RQ); Rule of Law (RL); Control of Corruption (CC) and Cost of Import. In the meantime, the ASEAN countries exceeded China on the governance indicators such as Voice and Accountability (VA); Political Stability (PV); Government Effectiveness (GE) and measurements of entrepreneurship (i.e. Cost of Business Start-up; Cost of Export; Cost of property registration; Cost of Import; and Time for Contract Enforcement).

Table 2 presents partial correlations among variables in the models. Across ASEAN and China, Government Effectiveness (GE), along with Regulatory Quality (RQ) and Control of Corruption (CC) are negatively correlated with Cost of starting a business $\left(Y_{C^{1}}\right)$ by quite high degrees: $-0.54 ;-0.66$ and -0.56 . Regulatory Quality (RQ) has negative correlations with Cost of Import $\left(Y_{C^{3}}\right)$ and Cost of Export $\left(Y_{C^{4}}\right)$ by respective values of -0.53 and -0.43 . Political Stability and No Violence (PV) and Rule of Law (RL) also act in a similar way on the Cost of property registration $\left(Y_{C^{2}}\right)$ and Time for contract enforcing $\left(Y_{T^{5}}\right)$ indicating the meaningful aspects of protecting the private sector in general and the entrepreneurs particularly across ASEAN+1.

\subsection{Hypothesis Testing}

Table 3 shows the results of regression analysis. It is shown that five logarithm regression models indicate very high degrees of $\mathbf{R}^{2}$ which are approaching the value of 1 with a negligible margin. This shows all of five models are robust and explaining quite completely the regression models' variances. Coupled with this, Durbin-Watson test confirmed that there was no violation of the co-linearity in the five regression models. As Singapore is the baseline in the five logarithm regression models, in this case the constant values are for Singapore. The other remaining ASEAN+1 countries could be compared on these five types of costs. Regression models show the results of hypothesis testing in Table 3 as follows. Hypotheses of from 1 to 5 were partially accepted because the beta coefficients in 5 regression models were not all negative. Namely, for hypothesis \#1, cost of starting a business was still positively impacted by government effectiveness (beta coefficient of 0.64 ) and control of corruption (beta coefficient of 0.21 ). With respect to hypothesis \#2, Cost of Property Registration was positively impacted by political stability (beta coefficient $=0.37$ ) and the Rule of Law (beta coefficient of 0.46 ). In hypotheses \#3 and \#4, costs of import and export were still positively impacted by the Rule of Law and Control of Corruption with corresponding beta coefficients of 1.27; 1.61; 1.23 and 2.06 as shown in Table 3. For hypothesis \#5, the contract enforcing time was impacted by Political Stability (beta coefficient of 0.01 ) and Government 
Table 1. Descriptive statistics of entrepreneurship and governance for ASEAN countries and China.

\begin{tabular}{ccccc}
\hline \multirow{2}{*}{ Variables } & \multicolumn{2}{c}{ ASEAN countries } & \multicolumn{2}{c}{ China } \\
\cline { 2 - 4 } & Mean & Std. Dev. & Mean & Std. Dev. \\
\hline Cost of business start-up & $54.0^{+}$ & 84.6 & 8.2 & 3.5 \\
Cost of property registration & $4.4^{+}$ & 2.8 & 5.8 & 0.2 \\
Cost of import & 519.7 & 240.8 & $521^{+}$ & 74.5 \\
Cost of export & $484.1^{+}$ & 283.0 & 481 & 67.0 \\
Time for contract enforcement & $53.2^{+}$ & 41.0 & 11 & 0.0 \\
Voice and accountability & $27.4^{+}$ & 13.9 & 10 & 5.6 \\
Political stability and no violence & $33.2^{+}$ & 27.2 & 32 & 2.0 \\
Government effectiveness & $48.4^{+}$ & 24.2 & 57 & 3.5 \\
Regulatory quality & 42.9 & 23.4 & $48^{+}$ & 3.5 \\
Rule of law & 38.1 & 22.5 & $42^{+}$ & 3.3 \\
Control of corruption & 31.4 & 26.8 & $36^{+}$ & 3.3 \\
\hline
\end{tabular}

Source: Calculated by authors from 2004-2014 WGI and WB Entrepreneurship data. Sign (+) indicates the dominant impact on the variable.

Table 2. Correlations among variables across ASEAN +1 countries.

\begin{tabular}{|c|c|c|c|c|c|c|}
\hline Variables & VA & PV & GE & RQ & RL & $\mathrm{CC}$ \\
\hline Cost of business start-up & -0.03 & $-0.35^{* *}$ & $-0.54^{* * *}$ & $-0.39^{* *}$ & $-0.66^{* *}$ & $-0.56^{* *}$ \\
\hline Cost of property registration & $0.25^{* *}$ & $-0.46^{* *}$ & $-0.17^{*}$ & -0.10 & $-0.26^{* *}$ & $-0.28^{*}$ \\
\hline Cost of import & $0.45^{* *}$ & $-0.14^{* *}$ & $0.43^{* *}$ & $-0.53^{* *}$ & $0.28^{* *}$ & $0.44^{* *}$ \\
\hline Cost of export & $0.36^{* *}$ & $-0.05^{* *}$ & $0.32^{* *}$ & $-0.43^{* *}$ & 0.19 & $0.34^{* *}$ \\
\hline Time for contract enforcement & $0.25^{* *}$ & -0.08 & $-0.41^{* *}$ & $-0.23^{*}$ & $-0.47^{* *}$ & $-0.38^{* *}$ \\
\hline
\end{tabular}

Note: The asterisks ${ }^{*}$ and ${ }^{* *}$ indicate statistical significance at $\alpha=0.05$ and $\alpha=0.01$

Table 3. Results of natural logarithm linear regression models.

\begin{tabular}{|c|c|c|c|c|c|}
\hline \multirow{3}{*}{$\begin{array}{l}\text { Independent } \\
\text { predictors }\end{array}$} & \multicolumn{5}{|c|}{ Dependent variables } \\
\hline & $\begin{array}{l}\text { Cost of starting } \\
\text { a business }\end{array}$ & $\begin{array}{l}\text { Cost of property } \\
\text { registration }\end{array}$ & Cost of export & Cost of import & $\begin{array}{c}\text { Contract } \\
\text { enforcing time }\end{array}$ \\
\hline & $Y_{C^{1}}$ & $Y_{C^{2}}$ & $Y_{C^{3}}$ & $Y_{C^{4}}$ & $Y_{T^{5}}$ \\
\hline Constant & $3.23^{* * *}$ & $1.79^{*}$ & $12.73^{* * *}$ & $13.79^{* * * *}$ & $3.17^{* * *}$ \\
\hline BR (Brunei) & $\underline{2.73}^{* * *}$ & $-1.17^{* * *}$ & $\underline{0.29}$ & $\underline{0.46}$ & $\underline{0.55^{* * *}}$ \\
\hline KH (Cambodia) & $\underline{4.63}^{* * *}$ & $\underline{0.02}$ & $\underline{0.45}$ & $\underline{0.40}$ & $\underline{1.49}^{* * *}$ \\
\hline CH (China) & $\underline{1.13}^{* * *}$ & $\underline{0.19}$ & $\underline{0.23}$ & $\underline{0.85}$ & $-0.72^{* * *}$ \\
\hline IN (Indonesia) & $\underline{3.45}^{* * *}$ & $\underline{1.40}^{* * *}$ & -0.27 & -0.10 & $\underline{1.82^{* * *}}$ \\
\hline LA (Laos) & $\underline{1.85}^{* * *}$ & $-1.01^{* * *}$ & $-5.87^{* * *}$ & $-5.77^{* * *}$ & $\underline{0.32^{* * *}}$ \\
\hline MA (Malaysia) & $\underline{2.89}^{* * *}$ & $\underline{0.15}$ & -0.05 & $\underline{0.09}$ & $\underline{0.21} \underline{1 * *}^{* * *}$ \\
\hline PH (Philippines) & $\underline{2.6}^{* * * *}$ & $\underline{0.80}^{* * *}$ & $\underline{0.33}$ & $\underline{0.77}$ & $\underline{0.14}{ }^{* * *}$ \\
\hline TH (Thailand) & $\underline{1.67}^{* * *}$ & $\underline{0.73} \underline{3 * *}^{* *}$ & -0.24 & -1.06 & $-0.38^{* * *}$ \\
\hline VN (Vietnam) & $\underline{2.42^{* * *}}$ & $-1.38^{* * * *}$ & -0.37 & $\underline{0.01}$ & $\underline{0.28}^{* * *}$ \\
\hline VA (voice \& accountability) & $-0.29^{*}$ & -0.07 & $\underline{0.24}$ & $\underline{0.52}$ & $\underline{-0.01}$ \\
\hline PV (political stability, no violence) & -0.22 & $\underline{0.37^{* *}}$ & $-0.39^{* *}$ & -0.21 & $\underline{0.01}$ \\
\hline GE (government effectiveness) & $\underline{0.64}$ & -0.34 & $-2.71^{* * *}$ & $-3.59^{*}$ & $\underline{0.11}$ \\
\hline RQ (regulatory quality) & -0.15 & -0.17 & $-1.41^{* * *}$ & $-1.6^{*}$ & -0.02 \\
\hline RL (rule of law) & $-1.04^{*}$ & $\underline{0.46}$ & $\underline{1.27^{*}}$ & $\underline{1.23}$ & -0.10 \\
\hline CC (control of corruption) & $\underline{0.21}$ & -0.41 & $\underline{1.61}^{* * *}$ & $\underline{2.06}^{* * *}$ & -0.02 \\
\hline $\mathrm{R}^{2}$ & 0.91 & 0.86 & 0.93 & 0.76 & 0.99 \\
\hline Adjusted $\mathrm{R}^{2}$ & 0.89 & 0.73 & 0.91 & 0.71 & 0.99 \\
\hline Durbin-Watson & 0.79 & 1.05 & 1.93 & 1.42 & 0.57 \\
\hline F-statistics & $16.19^{* * *}$ & $16.19^{* * *}$ & $70.13^{* * * *}$ & $17.34^{* * *}$ & $781.12^{* * *}$ \\
\hline
\end{tabular}

Note: The asterisks $\left({ }^{*}\right)$ indicates statistical significance $\alpha=0.05 ;{ }^{* *} \alpha=0.01 ;{ }^{* * *} \alpha=0.001$; Unstandardized coefficients in Ln regression models. 
Effectiveness with a beta coefficient of 0.11 at non-statistically significant level. Results of regression analysis confirmed the acceptance of the last sixth hypothesis across 5 models. Below is presented the discussion of the testing of the sixth hypothesis.

With regards to the cost of starting a business, ASEAN +1 countries have a rather high level of the start-up business expenditures. Especially, such countries as Cambodia, Indonesia, Malaysia and Brunei are leading champions in terms of bigger business start-up costs $\left(Y_{C^{1}}\right)$ while Vietnam, Thailand and China are having a smaller amount of costs $\left(Y_{C^{1}}\right)$ as compared to Singapore. Governance indicators on Government Effectiveness (GE) and Control of Corruption (CC) scored positive impacts of 0.61 and 0.21 respectively on costs of starting a business $\left(Y_{\mathrm{C}^{1}}\right)$ across ASEAN +1 countries. On the contrary, the remaining governance indicators such as VA; PV; RQ; and RL do exert negative impacts on the Costs of Starting a Business $\left(Y_{c^{1}}\right)$.

Concerning the Costs of Property Registration $\left(Y_{C^{2}}\right)$, such countries as Brunei, Laos, and Vietnam, with negative beta coefficients, indicate a lower level than Singapore's baseline of 1.79 while Cambodia, Indonesia, Malaysia, and the Philippines have higher degree of property registration costs than that of Singapore. Governance indicators on Government Effectiveness (GE); the Regulatory Quality (RQ) and Control of Corruption (CC) have negative impacts $\left(0.07 ;-0.17\right.$; and -0.42 respectively) on the costs related to property registration $\left(Y_{C^{2}}\right)$ across ASEAN+1. As opposed to these figures, the rest of governance measures such as Political stability and no Violence (PV) and the Rule of Law (RL) do exert negative impacts of 0.37 and 0.46 on the Cost of Property Registration $\left(Y_{C^{2}}\right)$.

Exporting as well as importing activities and their related costs are also major concerns for business start-up which serves as an indication of entrepreneurship development. Entrepreneurs of Brunei, Cambodia, China, Philippines tend to incur the larger costs of export and import than those of Singapore. Vietnam has a more prevailing cost of import than Singapore just with a narrow margin of 0.01. Concerning the governance indicators in the regression models in which Cost of export $\left(Y_{c^{3}}\right)$ and cost of import $\left(Y_{C^{4}}\right)$ are the dependent variables of such independent predictors as Voice and Accountability (VA); Regulatory Quality (RQ); and Control of Corruption (CC). These independent variables have a positive impact on both Cost of Export ( $\left.Y_{\mathrm{C}^{3}}\right)$ and Cost of Import $\left(Y_{C^{4}}\right)$ by respective coefficients of 0.24 ; 1.27 ; and 1.61 in $Y_{C^{3}}$ model, and 0.52 ; 1.23 and 2.06 in $Y_{C^{4}}$ model. As opposed to this, the remaining independent predictors such as Political Stability (PV); Government Effectiveness (GE); and Regulatory Quality (RQ) exert a negative impact on both dependent variables: Costs of export $\left(Y_{C^{3}}\right)$ and costs of import $\left(Y_{C^{4}}\right)$ with the regression coefficients of -2.17 and -1.41 in the $Y_{C^{3}}$ and -3.59 and -1.6 in the $Y_{C^{4}}$.

The last issue related to the entrepreneurship development is the time necessary for contract enforcement as described in World Bank dataset. As compared to the other remaining independent variables, contract enforcement time seemed to be exposed to the negative impact by six governance indictors to a lesser degree. In the regression model China and Thailand all have smaller impacts on the contract-enforcing time $\left(Y_{T^{5}}\right)$ as compared to Singapore's benchmark by respective beta coefficients of $-0.72 ;-0.38$; and -0.01 . In addition, the remaining ASEAN countries such as Brunei; Cambodia; Indonesia; Lao; Malaysia; and Vietnam have a higher degree of impact on the contract-enforcing time $\left(Y_{T^{5}}\right)$ than that of Singapore by a margin of $0.56 ; 1.50 ; 1.82 ; 0.32 ; 0.14$; and 0.28 on a respective basis. Across ASEAN +1 countries, the following governance indicators all have a positive impact on the contract-enforcing time $\left(Y_{T^{5}}\right)$ : Voice and Accountability (VA); Regulatory Quality (RQ); Rule of Law (RL); and Control of Corruption (CC) to respective degree of $-0.01 ;-0.02 ;-0.10$; and -0.02 . This indicates a promising signal for the effort that ASEAN +1 countries are trying in order to improve the governance performance in the region. However, Political Stability and Government Effectiveness shows that they still have a lot of things to do in an attempt to improve their business environment for entrepreneurship development in general, and make business contract enforceable for entrepreneurs in particular.

\section{Conclusions Policy Implications}

The testing shows that hypotheses from 1 to 5 are partially supported while the hypothesis \#6 is confirmed. The findings of this research lend meaningful implications to better understand the governance constraints in terms of business start-up cost; property registration expenses; export-import costs and time for contract enforcement that entrepreneurs are facing. Resulting impacts from those dimensions of governance on the constraints for entrepreneurs vary across ASEAN +1 countries. This is because governance performance within the region is quite diverse and non-importable across border as remarked by Acharya [45]. 
Positive impacts of Government Effectiveness and Control of Corruption on the business startup cost imply that ASEAN+1 countries face with a daunting task in order to ease this constraint for better doing business. Our study's results have somewhat contradicted with what Huynh et al. (2008) have found out. They concluded that only three of the six measures: Voice and Accountability, Political Stability, and the Rule of Law were significantly correlated with economic growth. Regulatory control, Control of Corruption, and Government Effectiveness were found to be insignificant. Given the fact that ASEAN's governance performance is lagging behind the other countries with an exception of Singapore [6], Government Effectiveness (GE) and Control of Corruption (CC) might be the two first-priority issues for ASEAN+1 countries to focus on. There have been anti-corruption campaigns, between now and then, taking place in China, Vietnam and Thailand in an effort to tidy their governance. Its momentum, however, should be maintained on a continuous and long-term basis in order to reduce the business start-up costs for private sector in general and the entrepreneurs in particular.

That governance unanimously has negative impacts on costs of export and import implies several practicalities for ASEAN+1 countries. In order to reduce these costs, the governance performance in ASEAN+1 should be enhanced and geared toward achieving these objectives. This, however, is not an easy job for ASEAN countries and China to do. This is because on one hand, ASEAN +1 are crimped by weakness in its three biggest economies. On the other hand, lackluster export markets and moderated investment have weighed on growth in Indonesia, Thailand, and Malaysia [6]. One food-for-thought solution for policy makers is to increase the intracountry trade within ASEAN countries itself as Khorshed [37] confirmed that this issue is very low and in most cases is declining overtime. With the exception of Malaysia-Singapore export trade, no other countries in ASEAN have a significant amount of trade with one another even though they have similar patterns of resource endowments in favor for labor-intensive production modes [8]. The other recipe for ASEAN+1 countries to effectively deal with the export and import issue is to boost up the negotiation with the United States and to quickly close the deal on Trans-Pacific Partnership known as TPP. Countries such as Brunei; Malaysia; Singapore and Vietnam are the case in point. The US matters ASEAN because of its potentials to become a gateway into the Asian region which is considered as one of the most diverse and rapidly growing region in the world [46] [47]. Having a consumer base of more than 600 million with a combined GDP of almost $\$ 2.5$ trillion, ASEAN is the third largest economy in Asia, and the seventh largest in the world. In this context, the Trans-Pacific Partnership is definitely a key component in the US rebalancing strategy towards Asia [46]. However, courting Washington without hurting Beijing can be a big dilemma for ASEAN countries. Therefore, reaching a satisfactory Trans-Pacific Partnership deal might be time-consuming [45].

Cost of property registration and time needed for contract enforcement are the last two issues in discussing the governance-entrepreneurship nexus. The governance performance is very much intertwined with this frontline of entrepreneurship development for ASEAN+1 countries in order to protect investors. Statistical evidence as mentioned above indicates the more stable the political situation is the lesser degree to which the property registration cost is perceived among entrepreneurs across ASEAN countries and China. Similar remarks can be made as to why the rule of law plays a critical role in keeping down the time needed for contract enforcement.

Khorshed [37] while studying the convergence of per capita GDP across ASEAN countries has shown that corruption is severely undermining development objectives in some of the ASEAN countries. It hinders economic growth, reducing efficiency, acting as a disincentive to potential investor, and above all, it diverts critical resources meant for economic growth and poverty alleviation [31]. In our research, control of corruption has reached expected goals of reducing the costs of property registration and time needed for enforcing the contract with a negative impact. These are the two hindrances for entrepreneurship development. However, control of corruption goes against our expectation because of its exertion of positive impacts on Cost of Starting a Business; Costs of Import and Export. This is reflected in our finding that the more Control of Corruption is perceived, the more cost of starting a business and costs of import and export are perceived to be borne by entrepreneurs across ASEAN countries and China. More efforts should be made by the community of scholars with the aim at creating a playing level field for private sector as far as governance is concerned [4] [48] [49].

Entrepreneurship is important in ASEAN+1 markets and its member countries' competitiveness [27] [50][52]. The ASEAN plus One is closing the income gap with advanced economies, but governance in the region has lagged behind its economic achievements [6]. Therefore, they are supposed to work out the essential elements of governance at specific stages of their own development. The Asian Development Bank [6] has indicated that governance in the 21st century requires the revitalization of the public service which should be geared toward stirring up the entrepreneurship development and thus creating sustainable growth in the region. Better 
public service delivery would assist ASEAN countries in creating a favorable business environment for entrepreneurs to be prosperous, thereby, reducing the costs and time of matter concerned. In essence, this aims to remove the constraints and develop the entrepreneurship in the region. Our research has found diverse impact of governance on the constraints for entrepreneurship, thereby contributing a better knowledge to explain the governance-entrepreneurship nexus in ASEAN +1 context. However, intervening variables that underline the above-mentioned relationship must be identified in more detail, so as to increase entrepreneurship given the lagging governance performance in ASEAN countries and China. Limitation of our research lies in the fact that the level of entrepreneurship development is indirectly measured in terms of costs and time facing the entrepreneurs. Therefore, generalization of the research results must be taken with due care given the nature of causal relationship [53]. Longitudinal research may be needed to ascertain the impacts of governance on entrepreneurship over time. Future research can also incorporate a more comprehensive array of variables [54]. Also, Korea and Japan can be included in order to examine the impacts of governance on the entrepreneurship in the context of ASEAN Plus Three (APT).

\section{References}

[1] World Bank (2014) Doing Business 2014: Understanding Regulations for Small and Medium-Size Enterprises. Comparing Business Regulations for Domestic Firms in 189 Economies. The World Bank, Washington DC. http://dx.doi.org/10.1596/978-0-8213-9984-2

[2] United Nations (2013) Is Good Governance Good for Development? Bloomsbury Academic.

[3] Ong, K. (2006) Enabling Effective Governance in ASEAN Community. CAPAM 2006 Biennial Conference, Sydney, 23 October 2006. http://www.asean.org/resources/

[4] Knoll, M. and Zloczysty, P. (2012) The Good Governance Indicators of the Millennium Challenge Account: How Many Dimensions Are Really Being Measured? World Development, 40, 900-915.

[5] Amorós, J. and Bosma, N. (2013) Global Entrepreneurship Monitor: 2013 Global Report.

[6] ADB (2013) Asian Development Outlook 2013: Governance and Public Service Delivery.

[7] Bower, E. (2011) Governance in ASEAN: The Next Generation. Center for Strategic \& International Study, South East Asia Program, Southeast Asia. Volume II, Issue No. 13, 3 August 2011.

[8] Deb, S. (2013) ASEAN’s Next Big Improvements in Its Business Environment in Next 5 Years. Business White Paper, Management Consultant, KPMG India.

[9] Wielemaker, M. and Gedajlovic, E. (2010) Governance and Capabilities: Asia’s Entrepreneurial Performance and Stock of Venture Forms. Asia Pacific Journal of Management, 28, 157-185. http://dx.doi.org/10.1007/s10490-010-9221-9

[10] Green, M. and Szechenyi, N. (2014) Power and Order in Asia: A Survey of Regional Expectations. A Report of the CSIS Asia Program.

[11] Roy, D. (2013) The Rise of China: What to Watch for. Asia Pacific Bulletin, No. 243, 3 December 2013, East-West Center.

[12] Thomas, N. (2009) Governance and Regionalism in Asia. Routledge, New York.

[13] Cronin, B.M. (2014) US Should Help Vietnam Counter China’s Coercion. Asia Pacific Bulletin, No. 269, 26 June 2014, East-West Center.

[14] Sun, Y. (2014) China’s New Calculations in the South China Sea. Asia Pacific Bulletin, No. 267, 10 June 2014, East-West Center.

[15] Acs, J., Desai, S. and Klapper, F. (2008) What Does Entrepreneurship Data Really Show? Small Business Economy, 31, 265-281. http://dx.doi.org/10.1007/s11187-008-9137-7

[16] Amorós, E., Cristi, O. and Minniti, M. (2006) Driving Forces Behind Entrepreneurship: Differences on Entrepreneurship Rate Level and Its Volatility across Countries. Frontier of Entrepreneurship Research, 29, Article 2.

[17] Carree, M. and Thurik, A. (2010) The Impact of Entrepreneurship on Economic Growth. In: Acs, Z.J. and Audretsch, D.B., Eds., Handbook of Entrepreneurship Research: An Interdisciplinary Survey and Introduction, Springer, New York, 557-594. http://dx.doi.org/10.1007/978-1-4419-1191-9_20

[18] Thai, M. and Turkina, E. (2014) Macro-Level Determinants of Formal Entrepreneurship versus Informal Entrepreneurship. Journal of Business Venturing, 29, 490-510.

[19] Williams, C. and Nadin, S. (2010) Entrepreneurship and the Informal Economy: An Overview. Journal of Developmental Entrepreneurship, 15, 361-378. http://dx.doi.org/10.1142/S1084946710001683 
[20] Bjørnskov, C. and Foss, N. (2008) Economic Freedom and Entrepreneurial Activity: Some Cross-Country Evidence. Public Choice, 134, 307-328. http://dx.doi.org/10.1007/s11127-007-9229-y

[21] Wennekers, S., Uhlaner, L. and Thurik, R. (2002) Entrepreneurship and Its Conditions: A Macro Perspective. International Journal of Entrepreneurship Education, 1, 25-68.

[22] Gedeon, S. (2010) What Is Entrepreneurship? Entrepreneurial Practice Review, 1, 16-35.

[23] Bettignies, J. and Brander, A. (2007) Financing Entrepreneurship: Bank Finance versus Venture Capital. Journal of Business Venturing, 26, 808-832. http://dx.doi.org/10.1016/j.jbusvent.2006.07.005

[24] Gentry, M. and Hubbard, R. (2000) Tax Policy and Entrepreneurial Entry. American Economic Review, 90, $283-287$. http://dx.doi.org/10.1257/aer.90.2.283

[25] Harper, D. (1998) Institutional Conditions for Entrepreneurship. Advances in Austrian Economics, 5, 241-275.

[26] McMillan, J. and Woodruff, C. (2002) The Central Role of Entrepreneurs in Transition Economies. Journal of Economic Perspectives, 16, 153-170. http://dx.doi.org/10.1257/089533002760278767

[27] Friedman, B. (2011) The Relationship between Governance Effectiveness and Entrepreneurship. International Journal of Humanities and Social Science, 1, 221-225.

[28] Haltiwanger, J.C., Jarmin, R.S. and Miranda, J. (2010) Who Creates Jobs? Small vs. Large vs. Young. US Census Bureau Center for Economic Studies Paper, No. CES-WP-10-17. http://dx.doi.org/10.3386/w16300

[29] Gugler, P. and Chaisse, J. (2009) Competitiveness of ASEAN Countries: Corporate and Regulatory Drivers. New Horizon in International Business.

[30] Desai, S. (2009) Measuring Entrepreneurship in Developing Countries. Research Paper No. 2009/10, UNU World Institute for Development Economics Research (UNU-WIDER), Helsinki, Finland.

[31] Friedman, A., Cox, P. and Tribunella, T. (2010) Relationships among World Governance Indictors and National per Capital Income Weighted by Environmental Sustainability. Journal of Advances in Business, 1, 37-54.

[32] Dreher, A. and Schneider, F. (2010) Corruption and the Shadow Economy: An Empirical Analysis. Public Choice, 144, 215-238. http://dx.doi.org/10.1007/s11127-009-9513-0

[33] Morrison, A. (2000) Entrepreneurship: What Triggers It? International Journal of Entrepreneurial Behavior \& Research, 6, 59-71. http://dx.doi.org/10.1108/13552550010335976

[34] Troilo, M. (2011) Legal Institutions and High-Growth Aspiration Entrepreneurship. Economic Systems, 35, $158-175$. http://dx.doi.org/10.1016/j.ecosys.2010.08.001

[35] Peter, B. and Savoir, D. (2000) Governance in the 21st Century: Revitalizing the Public Service (Canadian Center for Management Development). McGill-Queen’s University Press, Kingston.

[36] Cressy, R., Cumming, D. and Mallin, C. (2013) Entrepreneurship, Finance, Governance and Ethics. In: Poff, D.C. and Michalos, A.C., Eds., Advances in Business Ethics Research, Springer and Business Media, Dordrecht.

[37] Khorshed, C. (2005) What's Happening to per Capita GDP in the ASEAN Countries? An Analysis of Convergence 1996-2001. Applied Econometrics and International Development, 5-3.

[38] Kaufmann, D., et al. (2010) The Worldwide Governance Indicators Methodology and Analytical Issues. Policy Research Working Paper WPS 5430. The World Bank Development Research Group Macroeconomics and Growth Team June 2010.

[39] Wiklund, J., Davidson, P., Audretsch, D. and Carlson, C. (2011) The Future of Entrepreneurship Research. Entrepreneurship Theory and Practice, 35, 1-9. http://dx.doi.org/10.1111/j.1540-6520.2010.00420.x

[40] Rauch, A., Wiklund, J., Lumpkin, G. and Frese, M. (2009) Entrepreneurial Orientation and Business Performance: An Assessment of Past Research and Suggestions for the Future. Entrepreneurship Theory and Practice, 33, 761-787. http://dx.doi.org/10.1111/j.1540-6520.2009.00308.x

[41] Sternberg, R. and Wennekers, S. (2005) Determinants and Effects of New Business Creation Using Global Entrepreneurship Monitor Data. Small Business Economics, 24, 193-203. http://dx.doi.org/10.1007/s11187-005-1974-z

[42] World Bank and IFC (2014) Doing Business Data. http://doingbusiness.org/data

[43] Lowrey, Y. (2003) The Entrepreneur and Entrepreneurship: A Neoclassical Approach. Office of Advocacy, US Small Business Administration, Washington DC. http://dx.doi.org/10.2139/ssrn.744785

[44] WGI (2014) World Governance Indicators Data. http://data.worldbank.org/data-catalog/worldwide-governance-indicators

[45] Acharya, M. (2014) ASEAN Dilemma: Courting Washington without Hurting Beijing. Asia Pacific Bulletin, No. 133, 18 October 2014, East-West Center.

[46] Das, B. (2014) TPP: An Agreement to Bridge the US with ASEAN and Asia. Asia Pacific Bulletin, No. 268, 12 June 
2014, East-West Center.

[47] East-West Center (2014) ASEAN Matters for America, America Matters for ASEAN. East-West Center, 1601 EastWest Road, Honolulu, Hawaii, USA.

[48] GCR (2009) Corruption and Private Sector. Transparency International. Cambridge University Press, the Edinburgh Building, Cambridge CB2 8RU, UK.

[49] Cumming, D. and John, S. (2014) The Economic Impact of Entrepreneurship: Comparing International Datasets. Corporate Governance: An International Review, 22, 162-178.

[50] Huynh, K. and Jacho-Chávez, D. (2009) Growth and Governance: A Nonparametric Analysis. Journal of Comparative Economics, 37, 121-143. http://dx.doi.org/10.1016/j.jce.2008.08.003

[51] Gil, A., Yaron, Z. and Eyal, S. (2011) The Effect of Corruption on Entrepreneurship. DRUID 2011 on Innovation, Strategy, and Structure-Organizations, Institutions, Systems and Regions at Copenhagen Business School, Denmark, June 15-17, 2011.

[52] Ha, T.T. and Hanh, L.T.V. (2012) Identifying the Public Administration Reform Performance through the Lens of Provincial Competitiveness Index and GDP Per Capita in Vietnam. Modern Economy Journal, 3, 11-15. http://dx.doi.org/10.4236/me.2012.31002

[53] Hair, J., Anderson, R., Tatham, R. and Black, W. (2008) Multivariate Data Analysis. McGraw Hill Publishing House, Boston.

[54] OECD (2015) Entrepreneurship at a Glance 2015. OECD Publishing, Paris. 